\title{
Миссионер и просветитель Преподобный Трифон Вятский (1546-1612)
}

\author{
Владимир Помелов \\ ФГБОУ ВО «Вятский государственный университет», кафедра педагогики, Киров, Россия \\ ORCID: 0000-0002-3813-7745 \\ vladimirpomelov@mail.ru
}

\section{Людмила Сахарова}

ФГБОУ ВО Кировский ГМУ Минздрава РФ, кафедра гуманитарных и социальных наук, Киров, Россия ORCID: 0000-0002-6445-6416

slg75@rambler.ru

\section{Василий Сахаров}

ФГБОУ ВО «Вятский государственный университет», кафедра педагогики, Киров, Россия ORCID: 0000-0002-0155-6188

vas701@rambler.ru

В. Помелов, Л. Сахарова, В. Сахаров, The Saint Triphon of Vyatka as a missionary and an enlightener (1546-1612), Elpis, 22 2020: 41-44.

В. Помелов, Л. Сахарова, В. Сахаров, Święty Tryfon Wiacki jako misjonarz i oświeciciel (1546-1612), Elpis, 22 2020: 41-44.

\begin{abstract}
The article tells the story of the Saint Triphon of Vyatka. His missionary and enlightenment activities are characterized.
Streszczenie: Artykuł zawiera dane biograficzne świętego mnicha Tryfona z Vyatki, charakteryzujący jego działalność jako misjonarza i oświeciciela.
\end{abstract}

Аннотация: В статье приводятся биографические данные Преподобного Трифона Вятского, характеризуется его деятельность как миссионера и просветителя.

Keywords: Saint Triphon of Vyatka, the Vyatka land, Khlynov

Słowa kluczowe: święty mnich Tryfon Wiacki, Kraj Wiacki, Chłynów

Ключевые слова: преподобный Трифон Вятский, Вятская Земля, Хлынов

Преподобный Трифон Вятский выступил фактически основателем православного просветительства «на Вятке». Трифон Вятский (в миру Трофим Дмитриевич Подвизаев) родился около 1546 года в селе Малонемнюжском (Малая Немнюжка, Малая Немнюга, позднее Воскресенское) Пинежского уезда на реке Немнюге (ныне это деревня Совполье Мезенского района Архангельской области), в семье зажиточных крестьян Дмитрия и Пелагеи Подвизаевых. Он был младшим сыном в семье. При крещении получил имя Трофим. С детства воспитывался набожным человеком.

Биограф Трифона, вятский историк конца XIX в. И. М. Осокин отмечает, что достигнув совершеннолетия, склонный к иночеству юноша оставил родительский дом. В 1568 г. он принял монашество под именем Трифона в Пыскорском Спасо-Преображенском монастыре на Каме.

Через два года после принятия иночества он оставил монастырь и удалился на реку Нижнюю Мулянку, а затем на реку Чусовую, откуда был вынужден уйти в 1580 г., поссорившись с владельцами тамошних мест Строгановыми.

До прибытия в г. Хлынов - главный город Вятской земли (впоследствии Вятка, ныне Киров) он занимался миссионерско-просветительской деятельностью среди остяков и вогулов. Однако сведения о непосредственной миссионерской деятельности святого Трифона среди «инородцев», как доказывал видный историк Вятского края Павел Николаевич Луппов, по-видимому, сильно преувеличены.

Большее значение для христианизации и распространения просвещения имело косвенное воздействие, исходившее от монастырей в вятских городах Хлынове, Слободском и Елабуге, заложенных трудами преподобного Трифона.

Согласно «Житию преподобного отца нашего Трифона, Вятского чудотворца», удалившийся в муллинские леса пыскорский чернец Трифон был «грубъ 
и невежа». Обратившись со слезной молитвой к Богу, он попросил милости, «еже бы разумети еще книжнаго писания», и «оть того часа блаженный почалъ книжный складъ разумевати и Божественное Писание почитати» $[1$, с. 61$]$.

В город Хлынов Трифон пришел человеком зрелым, убежденным монахом, с целью «восполнить у вятчан скудость к душевному спасению» [2, с. 553].

Его деятельность на Вятской земле ведет отсчет с 1580 г. С именем Трифона справедливо связывают постройку Хлыновского Успенского (Трифонова) монастыря, закладка которого состоялась в 1581 г. Разрешение на отвод земли под монастырь дал сам царь Иван IV в 1580 г.

В 1588 г. во время пребывания преподобного Трифона в Москве царь Федор Иоаннович и Иов, патриарх Московский пожаловали ему «в домъ пресвятой Богородицы Божия милосердия иконы и книги и ризы и прочия церковные потребы.....» [1, с. 81]. Всего даров набралось на 12 подвод.

Наиболее ценным даром преподобный Трифон считал книги. Дары, или «вклады», в пользу церквей и монастырей всегда считались богоугодным делом и служили важнейшим источником формирования книжных собраний.

По данным историка В. А. Перевалова, за первое столетие царствования Романовых ими было пожаловано на Вятку более 30 книг поступивших, прежде всего, в Успенский Трифонов монастырь. Большая же часть книг все-таки покупалась, главным образом в Москве, на Печатном дворе.

Самым активным покупателем был Успенский Трифонов монастырь, приобретавший книги впрок, видимо для продажи. Самыми распространенными были азбуки, стоившие 1 копейку.

С именем Трифона мы связываем начало распространения книжной грамотности в главном городе Вятской земли - Хлынове. О письменности на Вятке до присоединения ее к Московскому государству сведений не сохранилось. Но она, несомненно, существовала, считал вятский профессор А. В. Эммаусский $[3$, c. 67].

И хотя до XVIII в. в Вятском крае не было школ, грамотность, тем не менее, существовала. Дети духовенства, купцов и приказных людей получали первоначальное образование у священников и у мастеров грамоты. В пользу данного утверждения говорит и то обстоятельство, что на раскопках Никулицкого городища, существовавшего задолго до рассматриваемых нами событий и находившегося в непосредственной близости от города Хлынова (впоследствии город Вятка, ныне город Киров) был обнаружен «стиль», или «писало», - заостренная костяная палочка, использовавшаяся для выцарапывания букв на бересте.

Как показывают исследования вятских и пермских ученых XX века (Е. Д. Петряев, А. Г. Мосин, В. Г. Шумихин, Г. Ф. Чудова и др.) Вятская земля издавна заслуженно слыла книжным краем. Книга и грамотность стали проникать в Вятку вместе с освоением края русскими людьми и распространением православия. Церкви и монастыри становились центрами просвещения, имели небольшие книжные собрания.

Первые документальные данные о распространении книг на Вятке относятся ко второй половине XVI в. и находят свое отражение в переписных, дозорных и писцовых книгах.

Особенно полные сведения имеются о библиотеке Успенского Трифонова монастыря, самой крупной в то время в Приуралье. В 1601 г., через 20 лет после своего основания, согласно дозорной книге Хлыновского Успенского монастыря в нем имелось 144 книги из которых 120 находились в монастырской библиотеке, 14 в келье Трифона. Основную часть библиотеки составляла, разумеется, богослужебная литература.

В то же время, почти отсутствует богословская (то есть философско-каноническая) литература, за исключением трудов Василия Великого. Имелось большое количество литературы духовно-нравственного содержания, прежде всего разных «Житий...» (почти $10 \%$ от общего числа книг).

Среди книг были две азбуки. Присутствуют «четьи книги»: житийные, церковно-назидательные, учебные и даже художественные: «Повесть о Варлааме и Иоасафе», два Пролога, Четьи-Минеи, Измарагд, творения Ефрема Сирина, Андрея Юродивого Аввы Дорофея, Иосафа Царевича, Лествичника, Книга Василия Великого, Жития Александра Свирского сочинения Кирилла Белозерского Прокопия Устюжского, Антония Римлянина, Стефана и Лазаря Сербских, Николая Чудотворца, десять Соборников, тетрадь о Печерском монастыре и др. [4, с. 95].

В келье Трифона хранилось 14 книг: четыре Псалтиря, молитвенник, богослужебные книги (Часослов, Постригальник, Служебник, Эпитимийник), Послание в монастырь, Азбучник (учебник, включавший азбуку, грамматику, арифметику и ряд справочных сведений), сборник канонов и акафистов.

Среди книг было и Житие самого Трифона, по-видимому, записанное с его слов и повествующее о его жизни до прихода в г. Хлынов. («Житие преподобного Трифона Вятского» написано специальным агиографом по заказу архиепископа Ионы; действительные факты из жизни Трифона переплетаются в нем с вымышленными).

Основную часть книжного фонда составляли рукописные книги (всего 91 книга) [5, с. 10-11, 16-17; 6]. На основании изучения рукописных источников исследователи пришли к выводу, что «перепиской книг занимался сам игумен Трифон, рукописи его письма были в числе его келейных книг» [6, с. 15].

В то же время, по мнению вятского историка В. В. Низова, почерк Трифона характеризует его как человека, не имевшего большой практики в письме [7, с. 201-202].

Конечно, библиотеки более старых и крупных монастырей Русского Севера и Центра, такие как Ки- 
рилло-Белозерский, Соловецкий, Троицко-Сергиев, превосходили книжными богатствами Успенский Трифонов монастырь в г. Хлынове [8, с. 225].

Но в сравнении со многими другими монастырями библиотека Успенского монастыря по составу книг выгодно выделялась. «Из самого беглого сравнения Успенского монастыря... даже с Пыскорским богатейшим монастырем... всякий вынесет убеждение, что Успенский монастырь 1601 года был далеко богаче Пыскорского 1624 года как иконами, так и книгами, несмотря на то, что Пыскорский был основан за 20 лет до Успенского» [9, с. 17-18].

Такое ценное собрание книг, отмечает И. М. Осокин, лучше всего свидетельствует о выдающейся любви настоятеля к просвещению, о любви монастырской братии к чтению. Оно дает право думать, что здесь существовало обучение грамоте и что чтением поручительных книг пользовались не одни только монахи, но и посторонние лица.

Другие вятские монастыри были значительно беднее книжными собраниями. В Троицком монастыре Слободского уезда в 1629 г. насчитывалось всего 32 книги, в Екатерининском - 25 [10, с. 225].

Успенский монастырь при преподобном Трифоне был, таким образом, весьма важным и, может быть, единственным на громадную территорию образовательным пунктом, где желающие могли удовлетворять свою потребность и в приобретении грамотности, и в дальнейшем просвещении.

По предположению И. М. Осокина, здесь воспитывался оставшийся неизвестным для потомков составитель жития Преподобного Трифона, вдумчивый, усердный собиратель сведений о жизни настоятеля монастыря знавший Священное Писание, святоотеческую литературу.

Вятский подвижник просвещения не только не изолировал общину от мирской жизни, но наоборот поставил монастырь в самую тесную связь с ней. В то же время, будучи сам приверженцем «строгой жизни» и «истовым совершителем богослужения» преподобный Трифон требовал того же и от духовенства.

Под влиянием примера его нравственного поведения постепенно начиналось духовное совершенствование, - сначала местных священников, а потом и мирян, - в духе христианского смирения, материального самоограничения и стремления к постижению священнических истин.

Тем самым, посредством распространения грамотности осуществлялся процесс нравственного развития местного населения.

Просветительская деятельность осуществлялась Трифоном и через храмы и часовни, возводившиеся в вотчинных землях, которые стали впоследствии территорией Слободского, Нолинского, Вятского и Малмыжского уездов Вятской губернии [11, с. 11].

Трифон был не только любителем книжного слова, но и сам обладал хорошим литературным слогом, о чем свидетельствует дошедшая до наших дней его духов- ная грамота. Роль преподобного Трифона в деле просвещения вятского народа далеко не ограничивалась только распространением грамотности.

Он проявлял себя и как строгий ревнитель нравственности, боровшийся с распространением дурных привычек. Так, в одной из его грамот, адресованной судейским целовальникам Вобловицкой вотчины имеется, в частности, такой наказ: «Велели есми вам... беречи накрепко, чтоб в Вобловицкой волости вин не курили и пив не варили без явочно, и воровства бы никоторого у них татьбы и разбоя... и душегубства не было, и буде кому надобе которому празднику или по родителям или на свадьбу вина оукурити или пива или браги пьяные сварити, им велети к вам являтися, а имати явки с четверти по денге и держати в вашей казне за печатью, а писати в книги, а буде который крестьянин тутошний оучнет вина курити или пиво или брагу пьяную на продажу варити, у тех людей то питье и сосуды винные вам имати, а их же пеню бити батогом» [4, с. 97].

Подобными проповедями он стремился бороться с пьянством, которое уже в те времена получило распространение в России, и в особенности «на Вятке». Распространению пьянства на Вятской земле во многом способствовало то немаловажное обстоятельство, что именно здесь местные жители-удмурты (ранее их называли вотяками) готовили по известному им рецепту из зерна спиртной напиток, который они называли кумыликой. Известный исследователь истории кулинарии Вильям Похлебкин считал, что само слово водка произошло от названия реки Вятка (по-удмуртски - ceребряная вода). Эту версию поддерживают некоторые вятские историки, тем более что в старину именно здесь обитало удмуртское племя ватка.

Около 20 лет преподобный Трифон Вятский возглавлял основанный им монастырь. Здесь он и скончался 8 октября 1612 г.

В историю Вятского края Трифон вошел как устроитель первых монастырей - Вятского Успенского и Слободского Богоявленского. Устройство этих монастырей - традиционного места устройства библиотек и переписи книг, послужило стимулом к началу книжной грамотности [12, 13, с. 33].

Именно с преосвященного Трифона на Вятке начинается первый этап распространения просвещения. Деятельность этого просветителя-священника во многом способствовала тому, что книга и грамотность стали достаточно распространенным явлением не только в церквах и монастырях, что вполне естественно, но также получили хождение среди мирского населения.

Результаты ряда исследований $[6 ; 7]$ позволяют утверждать, что в XV - начале XVII вв. на Вятской земле книги обращались среди населения: их заказывали, продавали, покупали, обменивали и дарили.

Некоторые состоятельные хлыновцы даже имели небольшие домашние библиотеки, причем кое-кто из них, «делал вклады»; например Петр Толмачев подарил Успенскому монастырю 12 книг [7, с. 206]. 
Постепенно книжная грамота, просвещение выходили за стены монастырей, постепенно проникала в среду населения. Таким образом, просветительская деятельность первых христианских проповедников Вятского края, подвижников Трифона Вятского имела важное значение для просвещения местных жителей.
Благодарные потомки хранят память о преподобном Трифоне Вятском. 1 июня 2015 г. в городе Кирове в одном из скверов в центре города ему был поставлен величественный памятник. Рядом с ним установлена впечатляющая бронзовая стела, изображающая храмы, которые были открыты на Вятской Земле Трифоном Вятским.

\section{Bibliografia}

1. Žitie prepodobnogo otca našego Trifona, Vâtskogo čudotvorca. (1868). Kazan' [Житие преподобного отия нашего Трифона, Вятского чудотвориа. (1868). Казань].

2. Gajda, V. V. (1999). Načinaâ s Trifona Vâtskogo. W: V. A. Sitnikova, (red.), Ènciklopediâ Zemli Vâtskoj: v X t. (t. 9. s. 553-565). Kirov. [Гайда, В. В. (1999). Начиная с Трифона Вятского. W: В. А. Ситникова, (red.), Энциклопедия Земли Вятской: в Х m. (t. 9. s. 553-565). Киров].

3. Èmmausskij, A. V. (1995). Kul'tura Vâtskogo kraâ XVII veka. W: V. A. Sitnikova, (red.), (1999). Ènciklopediâ Zemli Vâtskoj: vXt. (t. 4. s. 67-75). Kirov. [Эммаусский, А. В. (1995) Культура Вятского края ХVII века. W: В. А. Ситникова, (red.), (1999). Энциклопедия Земли Вятской: в Хm. (t. 4. s. 67-75). Киров].

4. Osokin, I. M. (1995). Značenie Prepodobnogo Trifona v istorii Vâtskogo kraâ. W: V. A. Sitnikova, (red.), Ėnciklopediâ Zemli Vâtskoj: v Xt. (t. 4. s. 91-98). Кirov. [Осокин, И. М. (1995). Значение Преподобного Трифона в истории Вятского края. W: В. А. Ситникова, (red.), Энциклопедия Земли Вятской: в Хm. (t. 4. s. 91-98). Киров].

5. Dozornaâ kniga Hlynovskogo Uspenskogo monastyrâ. (1901). W: Pamâtnaâ knižka Vâtskoj gubernii i kalendar' na 1902 g. (s. 10-25). Vâtka. [Дозорная книга Хлыновского Успенского монастыря. (1901). W: Памятная книжка Вятской губернии и календарь на 1902 г. (s. 10-25). Вятка].

6. Mosin, A. G. (1994). Ot Vâtki do Tobol'ska: cerkovno-monastyrskie biblioteki rossijskoj provincii XVI-XVIII vv. Ekaterinburg. [Мосин, А. Г. (1994). От Вятки до Тобольска: иерковно-монастырские библиотеки российской провинции XVI-XVIII вв. Екатеринбург].

7. Nizov, V. V. (1999). Knigi i čitateli srednevekovoj Vâtki. W: V. A. Sitnikova, (red.), Ènciklopediâ Zemli Vâtskoj: $v$ Xt. (t. 9. s. 189-206). Kirov. [Низов, В. В. (1999). Книги и читатели средневековой Вятки. W: В. А. Ситникова, (red.), Энцииклопедия Земли Вятской в Х m. (t. 9. s. 189206). Киров].

8. Kolupaeva, V. N., Sergeev, V. D. (1999). Iz istorii vâtskih bibliotek. W: V. A. Sitnikova, (red.), Ėnciklopediâ Zemli Vâtskoj: v Xt. (t. 9. s. 224-246). Kirov. [Колупаева, В. Н., Сергеев, В. Д. (1999). Из истории вятских библиотек. W: В. А. Ситникова, (red.), Энциклопедия Земли Вятской в Xm. (t. 9. s. 224-246). Киров].

9. Vâtskij Uspenskij monastyr' pri prepodobnom Trifone. (1906). Vâtka. [Вятский Успенский монастырь при преподобном Трифоне. (1906). Вятка].

10. Prokošev, V. V. (red.). (1976). Iz istorii narodnogo obrazovaniâ Urala. Perm'. [Прокошев, В. В. (red.). (1976). Из истории народного образования Урала. Пермь.].

11. Berova, I. V. (1989). Ansambl' Uspenskogo Trifonova monastyrâ. Kirov. [Берова, И. В. (1989). Ансамбль Успенского Трифонова монастыря. Киров].

12. Pomelov, V. B. (2016). Prosvetitel'skaâ deâtel'nost' svâŜennikov-podvižnikov Vâtsko-Kamskogo regiona Stefana Permskogo i Trifona Vâtskogo. W: Istoriko-pedagogičeskij žurnal, , 2 2016, 133-149. [Помелов, В. Б. (2016). Просветительская деятельность священников-подвижников Вятско-Камского региона Стефана Пермского и Трифона Вятского. W: Историко-педагогический журнал, 22016 , 133-149].

13. Pomelov, V. B. (2013). Prosvetitel'stvo russkoj pravoslavnoj cerkvi v rossijskoj provincii (na primere Vâtskogo kraâ). Saarbrûkken. [Помелов, В. Б. (2013). Просветительство русской православной церкви в российской провинции (на примере Вятского края). Саарбрюккен].

Rozmiar artykułu: 0,5 arkusza wydawniczego 